Stellenbosch Theological Journal 2016, Vol 2, No 1, 89-107

DOI: http://dx.doi.org/10.17570/stj.2016.v2n1.a05

Online ISSN 2413-9467 | Print ISSN 2413-9459

2016 ㄷ Pieter de Waal Neethling Trust

\title{
On the reception of Bonhoeffer - A case study of South-South dialogue
}

\author{
Smit, Dirk J \\ Stellenbosch University \\ djs1@sun.ac.za
}

\begin{abstract}
This article, read as a paper during a consultation on South-South receptions of Dietrich Bonhoeffer, argues that the late Russel Botman, Vice-Chancellor of the University of Stellenbosch and well-known South African ecumenical theologian, in his own person already served as a living illustration of such an encounter. He read and appropriated Bonhoeffer as a South African theologian, but in discussion and engagement with the work of several Latin American figures, including people who in different ways also read and appropriated Bonhoeffer. The article briefly shows how Botman developed three motifs that were central to his own life and thought by engaging a variety of Latin American figures - amongst others Leonardo Boff, Paolo Freire, Jon Sobrino, Juan Luis Segundo, Rubem Alves, Julio de Santa Ana, and Enrique Dussel - but always with a view also to Bonhoeffer, up to the point where it becomes difficult to distinguish any longer between the voices of Bonhoeffer, the voices of these thinkers from the South, and his own voice. The three motifs deal respectively with his concern for the next generation, his belief in imagination and hope, and his commitment to sociality and community.
\end{abstract}

Keywords

Russel Botman, Dietrich Bonhoeffer, Rubem Alves, hope

\section{Russel Botman's South-South Conversation}

Perhaps one could focus on the South-South nature of this Consultation ${ }^{1}$ by recalling the life, work and thought of Russel Botman, the former ViceChancellor of Stellenbosch University and the original founder of the

1 This essay goes back to a contribution to a panel discussion at the end of a Consultation on the reception of the work of Dietrich Bonhoeffer in South Africa and Latin America, respectively. 
Beyers Naudé Centre for Public Theology. ${ }^{2}$ As is well-known, his personal life and service in church and society, but also his public roles as professor, university manager and so-called thought-leader were all inspired by motifs from Dietrich Bonhoeffer, but what may be less known is the extent to which his own reception of Bonhoeffer was in turn informed and strengthened by figures and ideas from Latin America, in fact, by different figures during different stages of his biography, development and career.

In other words, it is indeed possible and hopefully instructive to remember the person of Russel Botman as an earlier example of the kind of SouthSouth contact and learning which this Consultation has been trying to achieve during these days. We are, in a manner of speaking, not the first meeting of this kind, since Russel Botman himself, in his person, already represented a similar kind of South-South encounter, learning experience and critical dialogue on the ongoing reception of the life and work of Bonhoeffer in and between different and diverse historical and social contexts in the global South.

For that purpose, I will offer three brief reminders of three central motifs in the life and work of Russel Botman. He developed all three of them in an ongoing and creative dialogue with the life, work and reception-history of Bonhoeffer, but in all three cases he also interpreted, understood and appropriated these three motifs from Bonhoeffer in a critical dialogue with Latin American thinkers and in some cases very explicitly with their own Bonhoeffer receptions in their contexts.

\section{A pedagogy of hope}

Perhaps one could begin with Botman's work as Rector and Vice-Chancellor of Stellenbosch University and his initiative behind what was known as the University's 'Hope Project'. ${ }^{3}$ It was an umbrella description of a focus across

2 For Russel Botman, see the still unpublished but forthcoming volume of essays commemorating his life and work, edited by Albert Grundlingh, Ruda Landman and Nico Koopman and published by the University of Stellenbosch, as well as the First Russel Botman Memorial Lecture, published as Dirk J Smit, "Making History for the Coming Generation' - On the Theological Logic of Russel Botman's Commitment to Transformation,' Stellenbosch Theological Journal Vol 1/No 2, 2015, 607-632.

3 For one of his many own descriptions of this project, see for example his lecture, 'The HOPE Project: A Rector's View on leading a Major Campaign in Africa,' input 
all faculties to somehow support and embody some of the international Millennium Goals, set by the global community to address major challenges in the world, by way of the teaching, research and community interaction activities of the University. The Council of the University whole-heartedly supported the Hope Project, all the faculties committed themselves to the project according to their own visions and strategies, and the whole university community was deeply and enthusiastically involved in what was a inspiring shared project, with many concrete, measurable and impressive results.

In his public speeches explaining the vision and the purposes behind the Hope Project, Botman often referred to the work of Paolo Freire, the Brazilian educator, called Pedagogy of Hope (his own later reworking and reinterpretation of his earlier study called Pedagogy of the Oppressed). Again and again, in many of his speeches, he acknowledged his indebtedness to some of the basic notions developed by Freire. ${ }^{4}$

Many others within the University followed suit and studied Freire for themselves - although one should remember that Freire's earlier work had already been read and used by many during the time of the struggle against apartheid, also on the campus of the University of the Western Cape, where Botman himself had been a student leader at the time. ${ }^{5}$ On one memorable occasion the Chairperson of the Convocation, representing all the alumni of Stellenbosch University, during one of the annual meetings of the Convocation, quoted extensively from Freire's work in order to participate

at the Conference of Rectors, Vice-Chancellors and Presidents of the Association of African Universities, June 2011 (accessible on the internet). For further information, see for example 'Hope as Guiding Concept for Stellenbosch University,' available online at http://hdl.handle.net/10019.1/80686; for additional information also www.thehopeproject.co.za.

4 See especially Paolo Freire, Pedagogy of Hope. Reliving Pedagogy of the Oppressed, London: Bloomsbury, 1994, but also already Freire, Pedagogy of the Oppressed, London: Penguin Books, 1972; for Botman's installation address, see http://hdl.handle. net/10019.1/211.65.

5 See the essay on theological developments during the struggle years on the campus of the University of the Western Cape by Mary-Anne Plaatjies-Van Huffel, 'A Chronology of the Political and Theological Activity at the University of the Western Cape during the Heyday of the Struggle against Apartheid,' in Umstrittene Beziehungen. Protestantismus zwischen dem südlichen Afrika und Deutschland von den 1930er Jahren bis in die Apartheidzeit. Contested Relations. Protestantism between Southern Africa and Germany from the 1930's to the Apartheid Era, Hanns Lessing, Tilman Dedering, Jürgen Kampmann, Dirkie Smit (eds), Wiesbaden: Harrassowitz Verlag, 2015, 500-508. 
in this discussion about the role of the University and its Hope Project - he clearly read the work himself in order to be able to contribute meaningfully to the internal discussions around Stellenbosch's future orientation and focus.

The truth was, however, that Russel Botman already had a passion for the youth, for children, for the next generation, for the future generation, for the generations to come, for students, for the children of our country, for the children of our continent, for the children of our world before he encountered the work of Paolo Freire, and that he was encouraged in this passion by his encounter with Dietrich Bonhoeffer. These expressions therefore abound in his earlier thought, even in his earlier publications, and when he began to read Bonhoeffer these were precisely some of the notions which caught his attention there and which attracted him to Bonhoeffer in the first place. In the same way, later during his studies and his scholarly career, these were once again the notions which drew him to a critical reading of and a learning encounter with Freire.

During his later years as Rector and Vice-Chancellor, also involved in leadership in tertiary education nation-wide and on the African continent, he increasingly and deliberately refrained from using explicit theological language, including direct references to Bonhoeffer. ${ }^{6}$ That was in line with

6 According to some, the ability to speak publicly and about issues of public concern but without using the language of faith and theology is one of the methodological characteristics of so-called public theology, which has become increasingly popular in recent years. It was in fact Russel Botman's vision to establish the Beyers Naudé Centre for Public Theology in the Faculty of Theology at Stellenbosch although. For a ground-breaking contribution on the notion of public theology, see his 'Theology after Apartheid: Paradigms and Progress in South African Public Theologies,' in Wallace Alston (ed), Theology in the Service of the Church, Grand Rapids: Eerdmans, 2000, 36-51. From early on, however, he already argued for this form of public involvement from the perspective of faith but without the language of faith, appealing to the wellknown sections in Bonhoeffer's letters and papers from prison where he described this as the task of the church in his day, for example: '(People of faith cannot) boast the final word on the formation of society. They will have to join society in a healing cycle of transformation. No clear lines are drawn between societal and ecclesial metaphors. A new language, understood by those in the church as well as by those outside, will have to evolve. I hope that the day that Dietrich Bonhoeffer dreamed of will soon dawn: the day when the people of South Africa will once again be called to speak the Word of God in such a way that the world is changed by it. We yearn for the dawn of a new language, perhaps, as Dietrich Bonhoeffer suggested, totally areligious but indeed liberating and redeeming as the language of Jesus Christ, by Almighty God and through the Holy Spirit. Indeed, it will disturb the people, but they will eventually surrender to the self- 
his understanding and practice of the task of public theology, but also in line with Bonhoeffer's words from prison about the new and secular language that would become necessary in the years to come. The challenge was how to speak the big words of the tradition of faith in such ways that everyone can understand what is meant and hopefully even relate to that. With this consciously in mind, Botman continued to use the same theological logic and in fact the same expressions and references - also developed in his earlier engagements with Bonhoeffer - without mentioning Bonhoeffer's name or their theological background. ${ }^{7}$

Up to some of his final speeches as Rector, he would therefore continue to speak about the urgent challenges implied in the question 'how the new generations would live,' 'those to whom the future belongs' ${ }^{8}$ - words which he found in a speech from Bonhoeffer during his ministry in Barcelona, which Botman also used as motto in his doctoral dissertation. ${ }^{9} \mathrm{He}$ was clearly interested in what Bonhoeffer so famously described in Letters and

validity enshrined in its message and actions,' quoted from his 'Dutch' and Reformed and 'Black' and Reformed in South Africa: A Tale of Two Traditions on the Move to Unity and Responsibility,' in Ronald Wells (ed), Keeping Faith. Embracing the Tensions in Christian Higher Education, Grand Rapids: Eerdmans, 1996, 103.

7 For this theological logic, also at work during his term as Vice-Chancellor, see my "Making History for the Coming Generation" - On the Theological Logic of Russel Botman's Commitment to Transformation,' Stellenbosch Theological Journal Vol 1/No 2, 2015, 607-632.

8 In the installation address as rector, for example, 'A Multi-Cultural University with a Pedagogy of Hope for Africa' (available on the internet), he referred to 'my dreams for a new generation of young people who will know apartheid only from hearsay,' without any direct reference to Bonhoeffer.

9 Although Botman quoted these words from earlier translations, and in fact mostly used his own paraphrases or even allusions to the Bonhoeffer text, see Dietrich Bonhoeffer, 'Basic Questions of a Christian Ethic,' in Barcelona, Berlin, New York. 1928-1931, Dietrich Bonhoeffer Works, Volume 10, Minneapolis: Fortress Press, 2008, especially 359-361. For Botman's repeated use of this allusion, see also for example Botman, 'Who is 'Jesus Christ as Community' for Us Today? The Quest for Community: A Challenge to Theology in South Africa,' JTSA March 1997, Vol 97, 35; as well as 'We cannot escape our theological responsibility to 'those to whom the future belongs' in obedience to God. The very existence of the generation of the future constitutes an 'ethos of responsibility' defined in terms of the future. The theological quest of any generation must never forget the generation to whom the future belongs,' in 'Dutch' and Reformed and 'Black' and Reformed in South Africa,' 103-104; similarly in 'Afterword: Is Dietrich Bonhoeffer Still of any Use in South Africa,' 372; also in 'Towards the Embrace of Political Reconciliation,' The Way: Review of Contemporary Christian Spirituality, 1999, 39(4):338-348; again in 'Human Dignity and Economic Globalisation,' NGTT, Vol 45 (1\&2), 326 . 
Papers from Prison as concrete responsibility, namely the attitude of those who do not seek how to get out of any difficulty saving their own face and serving their own advantage, but rather ask what they should do now, in the concrete present, even if that may prove humbling to themselves, so that the future generations may live. ${ }^{10}$

In fact, in his doctoral dissertation, Botman included three motto's. ${ }^{11}$ The first one was these words adapted from Bonhoeffer in which he dedicated the dissertation to their own children 'and the other children who will know apartheid only by hearsay.' The second one was from Proverbs 29:18 claiming that where there is no vision the people perish, although he added the word 'revelation' in brackets after vision, so that it implied that where there is no vision based on revelation the people perish. The third one was a reference to the Brazilian brothers Leonardo and Clodovis Boff reading that without a dream men and women will not mobilize themselves to transform society, nor will society seek to renew its own foundations, yet Christians believe that such a dream belongs to the realm of reality, for they have seen it in Jesus Christ.

In these three mottos and their internal logic, being related to one another, he clearly drew the intentions of his dissertation together. It is obvious how he felt indebted to ideas from revelation, as understood and appropriated by Bonhoeffer and by Latin American thinkers. In fact, in the dissertation it would become abundantly clear that Bonhoeffer and Latin American voices were for him not two separate traditions of reception of the gospel, but in fact closely intertwined with one another. He was indeed also informed and challenged by the Latin American reception of Bonhoeffer.

10 See for example the well-known passage in Letters and Papers from Prison on concrete responsibility, 'The ultimate question that responsible people ask themselves is not, How can I extricate myself heroically from the affair? but, How is the coming generation to live? It is only in this way that fruitful solutions can arise, even if for the time being they are humiliating. In short it is easier by far to act on abstract principles than from concrete responsibility. The rising generation will always instinctively discern which of the two we are acting upon. For it is their future which is at stake,' Dietrich Bonhoeffer, Letters and Papers from Prison, London: SCM Press, 1971, 138-139. Botman often used this quote in his own arguments, for example 'Die bevryding van Kain? Etiese nadenke oor die dader in die versoeningsproses,' in Scriptura 69(1), 111-124.

11 Russel Botman, Discipleship as Transformation? Towards a Theology of Transformation, unpublished doctoral dissertation, Bellville: University of the Western Cape, 1994. 
In the introductory section where he motivated the purpose of his study and explicitly asked why we should read Bonhoeffer in South Africa and whether Bonhoeffer could be of any significance in the South African search for a liberative Christology, he answered his own question by focusing 'on the reception Bonhoeffer had enjoyed in Latin America to clarify his relevance' also for South Africa. ${ }^{12} \mathrm{He}$ engaged with several Latin American authors and commentators on Bonhoeffer reception in Latin America (including Shaull, De Santa Ana, Schuurman, Bonino, Alves, and several others, especially Leonardo Boff and Jon Sobrino, and concluded that 'among others, the powerful influence of Bonhoeffer coincided with (a) the situation of rapid change in Latin America, (b) the need to create a responsive attitude among church members to the change, (c) the search for images, parables or what is presently called models and metaphors, (d) the questions of the Protestant mind, (e) and finally the faith commitment to Christ and to the Church.' ${ }^{13}$ One can already also recognize his selfunderstanding and his own intentions and program in these words with which he described his conclusions regarding Bonhoeffer in Latin America.

In particular, the emphasis on discipleship from Latin American Christology at the time and also from the life, work and reception of Bonhoeffer appealed to him. 'The 'imitatio Christi' or following of Christ which was being expounded by the most prominent scholars of Liberation Christologies' was for him 'the object of study of this research' - although the research was on Bonhoeffer. He intended to study that - in his words - as 'a paradigmatic category of historical transformation.' He therefore wanted to engage with Sobrino who 'aptly reminded us that the Christological question is actually a vocational and paradigmatic question. ${ }^{14}$ The question who Jesus Christ is included the question who we are, an insight which became of extreme importance in Botman's own thought and work, and he approvingly therefore quoted Sobrino's reference to Bonhoeffer that 'Christians are the ones who stay close to God in his passion.' ${ }^{\text {15 }}$

12 Botman, Discipleship as Transformation? Towards a Theology of Transformation, 48-53.

13 Botman, Discipleship as Transformation? Towards a Theology of Transformation, 50.

14 Botman, Discipleship as Transformation? Towards a Theology of Transformation, 50.

15 Botman, Discipleship as Transformation? Towards a Theology of Transformation, 50-51. 
Botman therefore claimed, 'It is clearly significant that Bonhoeffer and the theologians in Latin America came to grips with the concept imitatio Christi at a time and in a situation of severe oppression, exploitation and genocide which coincided with the quest for transition to democracy. Even more significant is the fact that Catholic liberation theologians found theological affinity and attachment to the conceptualisation of Dietrich Bonhoeffer. It is this significant relationship that prompted me to study Bonhoeffer as related to the quest for a liberative Christology. ${ }^{16}$

In the overall structure of his dissertation, this engagement with Latin American thought and particularly reception of Bonhoeffer then played a key role. In what he described as 'a brief but necessary interlude' he ended his own engagement with Bonhoeffer with 'read(ing) Segundo's Christology alongside my conclusions regarding Bonhoeffer' ${ }^{17}$ before he developed and presented his own final 'proposal towards a theology of transformation. ${ }^{18}$ This brief interlude in fact became a long and substantial engagement with Liberation Christology in general and with the work of Juan Luis Segundo's five volume work in particular. ${ }^{19}$ He was especially interested in the emphasis on discipleship, on the notion of the continuous making of contemporary gospels and on the epistemological shift which he found implied and at work in this project.

In Botman's own life many of these insights and convictions would remain of central importance, also as he was developing his own ideas concerning transformation as making history for the coming generations. ${ }^{20}$

\section{Tomorrow's children}

Behind this commitment to transformation as making history for the coming generations was again a conviction very typical of Russel Botman, but strengthened through his engagement with Bonhoeffer and with Latin

16 Botman, Discipleship as Transformation? Towards a Theology of Transformation, 51.

17 Botman, Discipleship as Transformation? Towards a Theology of Transformation, 175.

18 Botman, Discipleship as Transformation? Towards a Theology of Transformation, 208232.

19 Botman, Discipleship as Transformation? Towards a Theology of Transformation, 176207.

20 Botman, Discipleship as Transformation? Towards a Theology of Transformation, 121. 
American thinkers, including their reception of Bonhoeffer. It was the fundamental importance of the category of future, of tomorrow, of what is not yet but what is still to be, of what could already be imagined. Once again, the references to this conviction in Botman's own work are many and varied, they are found in diverse sources and contributions, and they are used in many different logics and arguments for multiple rhetorical purposes.

One crucially important theme, for example, was his life-long appropriation of Paul's argument in 1 Corinthians 7:29-31 that the world is passing away and the corresponding attitude to life should accordingly be one of living as if not. Already in 1988 he meditated on the key passage in 1 Cor. 7:29-31 where Paul argues that believers should live 'as if not' - should marry, work, possess, use this world 'as if they are not possessed by these' - because, in Paul's logic, in Christ 'the form of this world is passing away.' ${ }^{21}$ In later years, he would often again refer to this meditation and to the lasting influence of these ideas in his own life and thought. ${ }^{22}$

Pauline ethics is eschatological ethics, he argued, the form of this world is passing away, it is being transformed. This places the Christian in a critical relationship to the 'passing' form of the world or the passing status quo, he said, in a critical relationship known in theological circles as 'critical distance' or 'critical reserve'. Christians should therefore neither attempt to escape the realities of this status quo nor to accept it. 'When the Christian says 'no' to the sinful world, the Christian simultaneously shouts 'yes' for the new creation that is becoming a visible reality in our midst and

21 Russel Botman \& Dirk Smit, '1 Corinthians 7:29-31 'To live ... as if it were not!', JTSA 1988 , Vol 65, 73-79. In many ways, of course, these ideas corresponded to reflections by Bonhoeffer, for example in Dietrich Bonhoeffer, 'The Last Things and the Things Before the Last,' Ethics, London: SCM, 1978, 98-160: in the new edition and translation, Bonhoeffer, Ethics. Dietrich Bonhoeffer Works, Volume 6, 2005, Minneapolis: Fortress, Clifford Green, editor of the English Edition, 146-170.

22 See for example 'Theology After Apartheid: Paradigms and Progress in South African Public Theologies.' In Wallace Alston (ed), Theology in the Service of the Church: Essays in Honor of Thomas W Gillespie, 2000, Grand Rapids: Eerdmans, 47. When he receives the Kuyper Prize from Princeton Theological Seminary in April 2013, he still recalls the importance of this Pauline argument, see Botman, 'Dread, Hope, and the African Dream. An Ecumenical Collage,' in Gordon Graham (ed), The Kuyper Center Review, Volume Five: Church and Academy, Grand Rapids: Eerdmans, 2015, 1-25, esp. 20-21. 
times. ${ }^{23}$ On occasion he would motivate the longing for transformation in terms of the 'no', the suffering and the negative that people experience, but more often he would argue that the ultimate need for transformation is the 'yes', the promises and the positive, also already experienced, in which Christ takes form in reality and the present form passes away. For him, the Christian ethical stance over against the status quo is therefore based on the realisation that there is nothing absolute or definitive in or about the status quo because in Jesus Christ, on Good Friday and Easter Sunday, we have been allowed to see that 'the form of this world is passing.' For Christians, therefore, 'whatever exists is continuously relativized by that which can be and that which must be and that which undoubtedly shall be,' he said, in a phrase that he would repeat four times in this meditation, as a kind of motto. ${ }^{24}$

Botman would again recognize this conviction, so fundamental to himself, in many ways within Bonhoeffer's thought. Again only one crucial illustration would be Bonhoeffer's explication of the prayer for the kingdom in the Lord's Prayer, which Botman used on many occasions throughout his life, in diverse contexts and arguments. ${ }^{25}$

Right at the end of his dissertation, he argued that it had become time to move beyond a theology of resistance in South Africa to a theology of transformation. 'In this way theology will continue to be a theology of liberation (Segundo) for South Africa,' he said. Explaining what such a theology of transformation would mean, he claimed that '(T)he central question of a theology of transformation is the 'who?' question.' This drew on the whole of his earlier engagement with Bonhoeffer, in the preceding chapters. 'Who is the responsible person in South Africa today? The answer to this question is the same as the response to the question 'Who is Jesus Christ for us today?' This is true because discipleship is transformation.'

Bonhoeffer, of course, not only helped him to appreciate that discipleship is transformation, but also gave content, structure, format to the kind of

23 Botman \& Smit, 'To live ... as if it were not!' 77.

24 Botman \& Smit, 'To live ... as if it were not', JTSA 1988, 65.

25 Dietrich Bonhoeffer, 'Thy Kingdom Come,' in Berlin 1932-1933. Dietrich Bonhoeffer Works, Volume 12, ed. of English Edition L Rasmussen, Minneapolis: Fortress Press, 2009, 285-297. 
discipleship and the kind of transformation. He therefore immediately continued by lifting up the costly aspect of discipleship according to Bonhoeffer, which he illustrated with Bonhoeffer's use of the 'limping' of Jacob crossing the river into the new land. 'A theology of transformation does not make an offer of cheap grace. Instead, it calls us to the journey of discipleship, costly discipleship. It is the making of contemporary gospels at the cost of a gospel as we have seen in Jesus Christ (once again an allusion to Segundo at the heart of his reference to Bonhoeffer - DJS). We may enter the reign of God limping. ${ }^{26}$

Bonhoeffer made this link in his meditation on 'Thy Kingdom Come' and Bonhoeffer's whole argument and his use of the imagery clearly captured Botman's imagination, so that he would often, over many years, return to the same passage in Bonhoeffer at key points in his own papers and presentations, but in order to underline different themes all somehow present in the Bonhoeffer quote.

Since Botman often quoted these words at length, it may be informative to repeat the whole long quotation here, as the very last paragraphs and words of his doctoral dissertation.

'I want to conclude with the last words in Bonhoeffer's sermon on 'Thy Kingdom Come'. He reminds people that are in situations of transformation and reorientation about a strange story from the Old Testament. Jacob fled from his home and lived for many years in a foreign country in a state of enmity with his brother. Then the urge to return home and to his brother became insistent. He discovered later that it was only a small river that separated him from his brother. As he prepared to cross the river, he was stopped. A stranger wrestled with him. From this struggle a blessing was born: the sunrise!'

Up to here, it was a kind of paraphrase of Bonhoeffer's words, from now on he quotes Bonhoeffer directly.

"Then the sun rises on Jacob, and he proceeds into the Promised Land, limping because his thigh has been put out of joint. The way 
is clear; the dark door to the land of promise has been broken open. The blessing has come from out of the curse, and now the sun shines upon him. That the way of all of us into the land of promise leads through the night; that we also enter it as those who are perhaps curiously scarred from the struggle with God, the struggle for his kingdom and his grace; and that we enter the land of God and of our brother (and sister) as limping warriors - all these things we Christians have in common with Jacob. And we know that the sun is destined also for us, and this knowledge allows us to bear with patience the time of wandering and waiting and believing that is imposed upon us. But beyond Jacob, we know something else. We know it is not we who must go; we know that He comes to us...That is why we pray, thy kingdom comes to us,.'

He would later use several of these allusions from Bonhoeffer again in diverse contexts and in very imaginative and creative ways - particularly the motif of the sunrise as blessing; the memories of a long stay in a foreign country in a state of enmity with his brother; the urge to return home and to his brother; the realisation that the river separating him from his brother was actually small; the patience that is needed even in the new future; the limping of the warriors after the struggle; but also the waiting and the knowledge that Christ is coming, expressed in this prayer for the kingdom. ${ }^{27}$

Again, he would recognize several of these motifs in the work of a Latin American author, namely Rubem Alves' Tomorrow's Child. Imagination, Creativity, and the Rebirth of Culture. The title of the book already combined Botman's own passions for the future and for the youth - both strengthened by the way he read Bonhoeffer - and the subtitle brought together themes that were all crucial in his own life and thought, namely the power of imagination to think something completely different, the creativity of hope that acts, and the possibility that a whole culture can

27 See for example his essay 'Narrative Challenges in a Situation of Transition,' in Russel Botman \& Robin Petersen (eds), To Remember and to Heal. Theological and Psychological Reflections on Truth and Reconciliation, Cape Town: Human \& Rousseau, 1996, where he spoke of 'the rising sun of reconciliation,' 42-43; also his 'Towards the Embrace of Political Reconciliation,' The Way: Review of Contemporary Christian Spirituality, 1999, 39(4), 347-348. 
indeed be reborn, changed, renewed, or in his favourite term, transformed. Many of the issues treated in Alves' chapters - like the playfulness of children - would therefore resonate with Botman's own contributions. ${ }^{28}$

In fact, Alves also refers to Bonhoeffer, in the very last chapter of his study, called 'The Seed of the Future: The Community of Hope.' He quotes the words from Letters and Papers from Prison in which Bonhoeffer says 'Surely there has never been a generation in the course of human history with so little ground under its feet as our own. Every conceivable alternative seems equally intolerable' and then asks, 'How can we behave as if the world were free, and dance and play and celebrate as if we were not exiles?'29 It is precisely this 'as if' attitude and lifestyle - the italics are from Alves himself - which also fascinated and motivated Botman his whole life long, although he heard them already in Paul's eschatological ethics.

In 2000, around the time when Botman played a key role in taking the students and lecturers from the Uniting Reformed Church (URCSA) from the University of Western Cape to Stellenbosch and became Professor in Missiology in his new Faculty, he was invited to be part of the Campbell Seminar at the Columbia Theological Seminary in Decatur, GA. The group also included his ecumenical colleague Ofelia Ortega from Cuba. Their theme was 'Mission as Hope in Action' - an expression that Botman would often use and develop afterwards. ${ }^{30}$ Their contributions and findings were later published in a volume called Hope for the World. In one of his own

28 Rubem Alves, Tomorrow's Child. Imagination, Creativity, and the Rebirth of Culture, San Francisco: Harper \& Row, 1972. The major second part of Alves' study deals with 'Imagination and the Logic of Creativity,' 62-181.

29 He refers to a translation of Dietrich Bonhoeffer, Letters and Papers from Prison, London: Macmillan, 1953, 13-14, in Alves, Tomorrow's Child, 191, from the last chapter, 182-205.

30 This opportunity to do research and to collaborate with international scholars on the theme of hope had a real impact on Botman's thought, as would become clear from several of his contributions since then, including his own inaugural lecture in the Stellenbosch Faculty, but he was also inspired by the work on hope by the celebrated South African missiologist David Bosch, for example his early formulation in 'Prisoners of History or Prisoners of Hope,' The Hiltonian No 114, March 1979, and his later small booklet Believing in the Future, Valley Forge: Trinity Press International, 1995; in addition to his well-known major works on mission and hope, including the monumental Transforming Mission, Maryknoll: Orbis, 1991. 
essays in this collection, he would make the importance of a shared SouthSouth perspective for his own thought abundantly clear. ${ }^{31}$

Once again, he opened with a quote from Bonhoeffer's meditation on 'Thy Kingdom Come' which he used as motto. No-one can pray for the kingdom who has their own ideas of the kingdom, who lives for their own worlds, and who knows a thousand programs and prescriptions by which they would like to cure the world, Bonhoeffer said, in Botman's motto. Discipleship according to Bonhoeffer, he then argued, 'necessitates a hermeneutical readjustment to the sites of the poor and the marginalized in the world.' The new acts that God is doing are happening 'also in the unexpected places.' Therefore, '(r)emaking Christian hope requires specific attention to the poor and marginalized people of the Southern Hemisphere (Africa, Asia, the Caribbean, Latin America) and its diaspora in the north.' For him this meant that '( $\mathrm{f})$ uture leadership in Christianity will have to come from the Southern Hemisphere as the number of Christians continues to grow in these regions. 'Hope in action' will have to include 'investment in religious leadership, theological education, and projects that confess hope in action in the Southern Hemisphere and, also, its diaspora living in the north.' Such hope in action will therefore also challenge 'Christians in the Southern Hemisphere to take responsibility for enacting social hope by confession hope in action' - of which he provided several examples, many of them taken from the contexts of the Southern Hemisphere and from what he could 'imagine' happening there. ${ }^{32}$

\section{Ethics in community}

The third motif is one that actually developed only gradually in his own thought over the years, again often informed and inspired by other thinkers from the South.

31 Botman delivered an initial paper on 'South Africa and the Confession of Belhar: A Contemporary Confessing Journey toward Mission,' and a final contribution on 'Hope as the Coming Reign of God.' Both were published in Walter Brueggemann (ed), Hope for the World. Mission in a Global Context, 2001, Louisville: Westminster John Knox, respectively 31-34 and 69-82.

32 Botman, 'Hope as the Coming Reign of God,' especially 78-89, and for the importance of imagination, which he uses as a rhetorical device, $80-81$. 
During his earliest years he was making use of Bonhoeffer's understanding of discipleship, also since this helped him to underline the importance of being disciples in public life, in politics and in the world of everyday realities, in apartheid South Africa. From Bonhoeffer he increasingly learnt to express this search in the form of questions dealing with the responsible relationship between being disciples and being citizens. ${ }^{33}$ During the early years of the South African transition to a democratic society, this conviction that Christians were called not only as disciples but precisely as disciples also called as responsible citizens was indeed very appealing to many and a very constructive contribution. When he was accepted as Fellow at the Center of Theological Inquiry in Princeton, he in fact formulated the theme for his research project as 'Discipleship and Citizenship. ${ }^{34}$

Years later, reflecting back when receiving the prestigious Abraham Kuyper Prize in Princeton, he narrated his life-story in his acceptance speech called 'Dread, Hope and the African Dream: An Ecumenical Collage' by telling the audience how he realized, during their first week at the CTI in Princeton, working in the library, that this was in fact the wrong theme to pursue at the time, that his topic and his question were too small, that the world in which disciples are called to responsible transformation was much larger and more complex than (merely) politics, church-state relations and citizenship. ${ }^{35}$

33 See for example Botman, Discipleship as Transformation? Towards a Theology of Transformation, 118-124.

34 At the time he was also interested in questions of nation-building, and several of his contributions raised the issue, but together with his growing insight that the challenges were broader than merely South African issues, he increasingly wrote less about nationbuilding and citizenship. For some of these earlier essays, see for example 'Managing Endings and Transforming Continuities,' in Charles Villa-Vicencio and Carl Niehaus (eds), Many Cultures, One Nation, 152-162; 'Dutch' and Reformed and 'Black' and Reformed in South Africa'; his paper at the International Bonhoeffer Conference in Cape Town, in which he actually entertained the notion of 'discipleship as nation building,' published as 'Who is 'Jesus Christ as Community' for us today? The Quest for Community: A Challenge to Theology in South Africa,' JTSA March 1997, Vol 97, 30 38; extremely interesting and clear was the short paper on 'Towards a World-Formative Christianity in South Africa,' in Mongezi Guma \& Leslie Milton (eds), An African Challenge to the Church in the $21^{\text {st }}$ Century, 1997, Cape Town: Salty Print, 72-79.

35 Botman, 'Dread, Hope and the African Dream: An Ecumenical Collage,' 18 April 2013; see also an earlier account in 'A Cry for Life in a Global Economic Era,' 379-381. See also already earlier, Botman, 'A Cry for Life in a Global Economic Era,' in Wallace Alston \& Michael Welker (eds), Reformed Theology: Identity and Ecumenicity, 2003, Grand Rapids: Eerdmans, 375-384. 
The real challenge, he now understood, was not (merely) how to be church and citizens in South Africa, but how to be human in our globalising world. During these years he would increasingly think about and often speak and write about the oikos. ${ }^{36}$

In theological circles, Botman became one of the leading thinkers to rediscover and popularise this notion, arguing for an ethics of discipleship as responsible transformation in the ecumenical church, the global economy and the threatened ecology. His many and lasting contributions in this regard are well-known and widely respected. In the development of this third motif, however, thinkers from Latin America would once again inform and inspire him, as he also readily admitted. He acknowledged in particular the work and influence of Julio de Santa Ana, the Methodist theologian of liberation who worked for many years in ecumenical circles and whom Botman knew personally, as well as Enrique Dussel, the Argentinian-Mexican philosopher of liberation, whose work Botman read.

Botman opened his own instructive essay called 'The oikos in a Global Economic Era. A South African Comment' with a reference to De Santa Ana's question 'Is sustainable society possible in the context of globalization?,' calling that 'a difficult question.' He was referring to the volume which De Santa Ana edited shortly before, namely Sustainability and Globalization. It was obvious that Botman found this question intriguing and increasingly central to his own thought. He described this as 'a significant question' since it related 'the issue of sustainability' with 'the issue of sociality' - and this also intrigued him. 'In as much as the destruction of creation spells

36 See for example Botman, 'The Oikos in a Global Economic Era. A South African Comment,' in James Cochrane \& Bastienne Klein (eds), Sameness and Difference, 2000, Washington: The Council for Research in Values and Philosophy, 269-280. He did use the notion of household already in earlier essays, for example 'Dealing with Diversity,' 167-169, but now he developed it more fully and in greater detail. Oikos literally means household and it is the root still found in words like ecumenism (for the whole church of the whole world), economy (for the laws of the household, the ways in which the household is administered and cared for) and ecology (for the integrated and mutually dependent life-systems of the whole of reality, intimately belonging together as one). In the Greek New Testament the term is well-known for the household of God and in fact for the divine economy, by which the Triune God administers, cares for, blesses and saves the whole of creation, although this root is often completely translated away in modern languages. 
doom, the destruction of the moral and social centers of community' was also at stake in the context of globalization, he argued. ${ }^{37}$

It is this link between sustainability and sociality, between (potential consequences of) globalization and (the possibilities of ethical life in) community, that fascinated Botman. He found that also in the thought of Enrique Dussel, who argued that 'goodness is communal,' who claimed that 'ethics is not primarily a set of principles (but) the praxis of a community', who showed 'how important the relationship between ethics and community is to the project of liberation theology.' At the time, Botman was particularly referring to Dussel's Ethics and Community. 'I will argue,' he said, 'using Dussel's point, that the very essence of ethical community, reflected in the holistic world of the biblical oikos, is under attack in the context of economic globalization. ${ }^{39}$ Years later, receiving the Kuyper Prize, he would once again explicitly quote Dussel in this regard, reflecting back on the influences in his own life and thought. ${ }^{40}$

The interesting fact is that, in this argument, Botman once again appealed to Bonhoeffer, and in a way read Bonhoeffer once again through the eyes of these Latin American thinkers. 'Dietrich Bonhoeffer earlier developed the most comprehensive theological argument of the oikos concept in so far as it pertains to church and theology,' he claimed. Referring to Bonhoeffer's views on creation, Christology, ecclesiology, relationships with others, and the importance of what he often called the 'who-question' for Bonhoeffer, he argued that, for Bonhoeffer, life was about community, relationships, sociality, being-for-others, and about ethics, and that this was true even

37 Botman, 'The Oikos in a Global Economic Era. A South African Comment,' 269.

38 Enrique Dussel, Ethics and Community, Maryknoll, New York: Orbis, 1988.

39 Botman, 'The Oikos in a Global Economic Era. A South African Comment,' 269.

40 'I became convinced that the crucial theological discourse in the context of economic globalization is the oikos discourse. With Enrique Dussel I believe that the very essence of ethical community, reflected in the holistic world of the biblical oikos, is under attack in the context of economic globalization. What is at stake is the Christian faith or affirmation that God who created this world in covenantal relationships, continues to sustain it and its living organisms. Globalization includes and excludes peoples and countries by its very nature, by its particular set of preferences and penalties applied variously to those who engage with or challenge its forces. In essence, it fragments the oikos on the basis of a particular nomos (law) that takes precedence over the community. This is the dread we have to overcome,' Botman, 'Dread, Hope, and the African Dream. An Ecumenical Collage.' 
for prayer, as 'life together,' while after all 'Christ exists among us as community in the hiddenness of history. ${ }^{31}$

All of this brought him back, once again, to his favourite reference to Bonhoeffer's 'Thy Kingdom Come,' namely that no-one can pray for the kingdom who thinks up a kingdom for themselves, who lives for their own worldviews, and who knows a thousand programs and prescriptions by which they would like to cure the world. With this Botman clearly linked the third motif - of sociality, community and belonging - with the second motif of the future, prayer and imagination.

Interestingly enough, he continued by linking these two motifs directly with the first motif as well, namely hope for those who are still to come. 'Co-operation, as acting for the sake of others, even future others (my italics, DJS), is the only way to live in such a community-formed reality,' he concluded. Once again, he immediately put this in Bonhoeffer's own words as well, 'Thinking and acting for the sake of the coming generation (my italics, DJS), but being ready to go at any day without fear of anxiety that, in practice, is the spirit in which we are forced to live. ${ }^{34}$

Therefore, '(c)ommunity and its values of co-operation are crucial for future generations. As such it is inherently part and parcel of the quest for sustainable society' - by now it is no longer possible to discern whether this is the voice of Bonhoeffer, the voice of these liberation thinkers - educationalists, theologians, economists, philosophers - from Latin America, or the voice of Russel Botman himself. In his work and thought, these voices encountered and influenced one another too much to distinguish meaningfully between them, any longer. Together they already constituted a real South-South engagement, with the reception of Bonhoeffer's life and work at the heart of the event of appropriation.

\section{Reading Bonhoeffer together}

One can only speculate, but against this backdrop, it sounds indeed plausible that Russel Botman would have supported the suggestions made

41 Botman, 'The Oikos in a Global Economic Era. A South African Comment,' 272-273.

42 Bonhoeffer, Letters and Papers from Prison, 1971, 15, quoted by Botman, 'The Oikos in a Global Economic Era. A South African Comment,' 273. 
during this Consultation to pursue further such South-South encounters, also with the reception of Bonhoeffer in mind, and indeed also similar encounters in a BRICS context, as was proposed. For him, the question how the next generation is going to live, the awareness that the present form of the realities we know may be passing away, and the commitment that together we are called to make history all lead to the importance of such encounters for our common search. 